\title{
灌水後におけるセル成型苗個体群の純光合成速度，蒸発散速度， 顕熱輸送速度および潜熱輸送速度の变動
}

\author{
渋谷俊夫・北宅善昭*・古在 豊 樹 \\ 千葉大学園芸学部 $\cdot *$ 大阪府立大学農学部
}

\author{
Changes with Time in Rates of Net Photosynthesis, Evapotranspiration and \\ Sensible and Latent Heat Transfers of the Plug Sheet after Watering \\ Toshio Shibuya, Yoshiaki Kitaya* and Toyoki KozaI \\ Faculty of Horticulture, Chiba University, Matsudo, Chiba 271, Japan \\ * College of Agriculture, Osaka Prefecture University, Sakai 593, Japan
}

\begin{abstract}
Characterizing mass and energy balance at a plug sheet consisting of plug seedlings and soil mix is essential for optimum control of soil-mix moisture in plug seedling production. Time courses of rates of net photosynthesis, evapotranspiration and sensible and latent heat transfers of a tomato plug sheet under artificial light and the volumetric percent water content of soil mix were estimated micrometeorologically using the measured data on $\mathrm{CO}_{2}$ concentrations, dewpoint temperatures at two heights above the plug sheet and weight of the plug sheet measured with an electronic balance. The first watering was done at the start of measurements and the second watering 16 hours after the first watering. After the first watering, the volumetric percent water content of soil mix decreased with time. Sensible heat transfer rate increased, and evapotranspiration and latent heat transfer rates decreased with decreasing volumetric percent water content when it was lower than about $20 \%$. Net photosynthetic rate decreased with decreasing volumetric percent water content when it was lower than about $12 \%$. One to three hours after the second watering, all the rates returned to the levels at the start of measurement. The present method is useful for on-line monitoring of micrometeorological and water-stress status of the plug sheet and for automatic watering based upon the status.
\end{abstract}

(Received March 28, 1997)

1997 年 3 月 28 日受付

\section{緒言 \\ セル成型苗はセルトレイ上において高栽植密度の個} 体群を形成しており，個体群上には特有の境界層が形 成されている (Kim et al., 1996a)。近年，セル成型苗 個体群（苗および培地を含む系と定義し, 以下, 苗個 体群と呼ぶ）における物質および熱収支の解析が，野 外の植物個体群におけるそれらの解析方法（例えば, Lemon, 1963）を応用して行われている（Kim et al., 1996a ; 1996b ; Shibuya et al., 1997). セル成型苗は, 100 から 300 個程度のセルからなるセルトレイ（幅約
$300 \mathrm{~mm} \times$ 長さ約 $600 \mathrm{~mm}$ ）を用いて育成され，セルあ たりの培地量は 5 から $20 \mathrm{~mL}$ 程度と比較的少ないこ とから, 培地の保持できる水の量が少ない（Milks et al., 1989).このような培地の特性は, 苗個体群におけ る物質および熱収支特性に大きく影響すると考えら れ, その影響を明らかにすることは, セル成型苗生産 における環境調節技術, 特に灌水管理技術の確立に重 要である。

本研究では, セル成型苗生産における灌水管理技術 の確立のための基礎データを得ることを目的として， 人工光型グロースチャンバ内で培地の水分状態の変動 に伴うセル成型苗個体群の純光合成速度, 蒸発散速度, 
顕熱輸送速度および潜熱輸送速度の変動を, 先に報告 した微気象学的方法と科量法を応用した計測方法 (Shibuya et al., 1997) を用いて動的に計測した.さら に本研究では, これらの計測值から苗個体群の水利用 効率, ボーエン比および水蒸気拡散抵抗を求めた.

\section{材料および方法}

\section{1. 供試材料}

植物材料には温室内で播種後約 1 か月間育成された ナス (Solanum melongena L., 品種: 千両二号) のセ ル成型苗を用いた。実験に用いた苗個体群の概要を Table 1 に示す。

\section{2. 計測方法}

苗個体群をグロースチャンバ（日立製作所製）内に 設置した (Fig. 1).グロースチャンバ内の気温, 相対 湿度, $\mathrm{CO}_{2}$ 濃度, 気流速度, 光合成有効光量子束密度 および短波放射束密度を Table 2 に示す.グロース チャンバ内の気流方向はほほ水平であった。グロース チャンバの光源にはメタルハライドランプ(DR400/T, $\mathrm{DR} 125 / \mathrm{T}$ ，東芝ライテック(株)製）と高圧ナトリウム ランプ $(\mathrm{NHR} 360 ・ \mathrm{~L}$, 松下電工(株) 製) を併用した。 苗個体群上の 2 高度 $z_{1}, z_{2}$ における露点温度, $\mathrm{CO}_{2}$ 濃 度および気温を，それぞれ鏡面式露点計（Model 911， Digital Humidity Analyzer, EG\&G 製), 赤外線 $\mathrm{CO}_{2}$ 分 析計(IR21-2-MV, 横河電機 (株) 製)および熱電対（銅コンスタンタン, 線径 $0.1 \mathrm{~mm}$ ) を用いて計測した. 苗 個体群の重量を電子天科（EB-2800，(株)島津製作所 製)を用いて計測した。本実験において, $z_{1}$ おび $z_{2}$ を 苗個体群のキャノピーからの高さ $0 \mathrm{~mm}$ および $30 \mathrm{~mm}$ とした。計測装置の模式図を Fig. 2 に示す。エアポン プを用いて,苗個体群上の 2 高度 $z_{1}, z_{2}$ の空気をそれぞ れ空気採取用パイプ (内径 $2 \mathrm{~mm}$, アルミニウム製) か

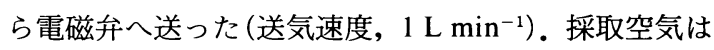

Table 1 Description of the plug sheet.

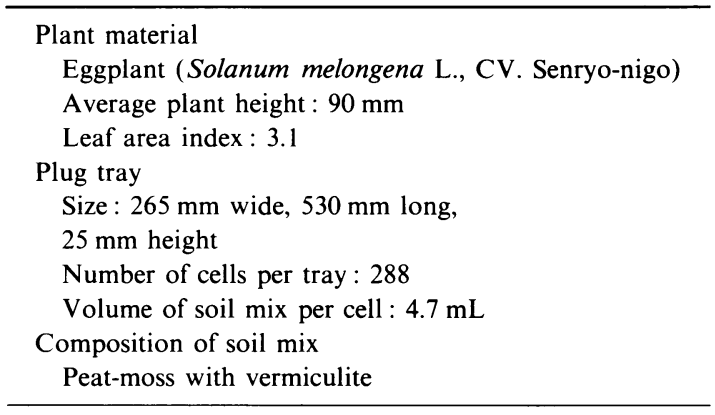

電磁弁が通電状態のときには IN から NCへ, 非通電 状態のときにはIN から NOへ流れた. 電磁弁を 2 分 間隔で順次通電状態にすることによって各高度の採取

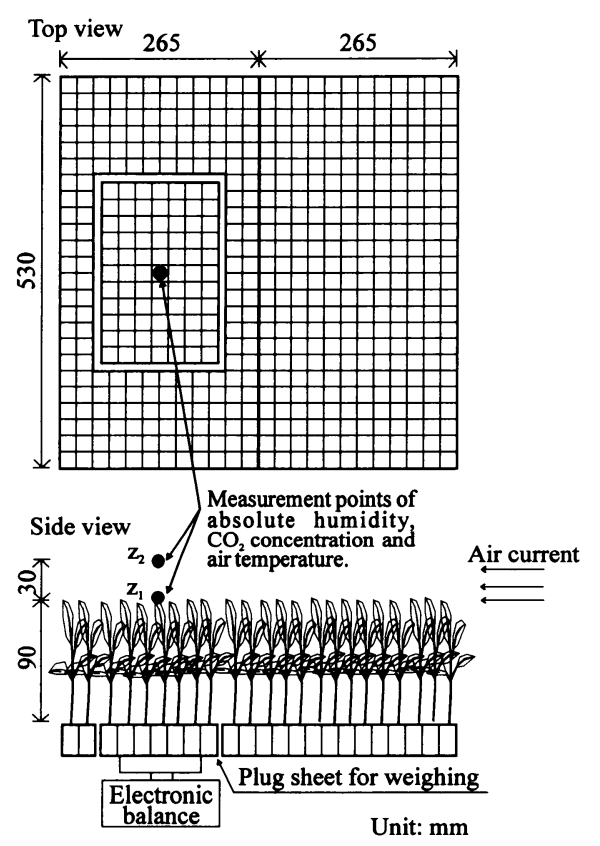

Fig. 1 Schematic diagram of the measurement method.

Table 2 Description of environmental conditions in the growth chamber.

\footnotetext{
Air temperature* : $30 \pm 1^{\circ} \mathrm{C}$

Relative humidity* : $60 \pm 3 \%$

$\mathrm{CO}_{2}$ concentration* : $340 \pm 30 \mu \mathrm{mol} \mathrm{mol}^{-1}$

Air current speed ${ }^{*}: 0.1 \mathrm{~m} \mathrm{~s}^{-1}$

Photosynthetic photon flux density on the canopy : $450 \mu \mathrm{mol} \mathrm{m}^{-2} \mathrm{~s}^{-1}$

Shortwave radiation flux density on the canopy : $250 \mathrm{~W} \mathrm{~m}^{-2}$

${ }^{*}$ Measurements of air temperature, relative humidity, $\mathrm{CO}_{2}$ concentration and air current speed were made at $z_{2}(30 \mathrm{~mm}$ above the plug sheet).
}

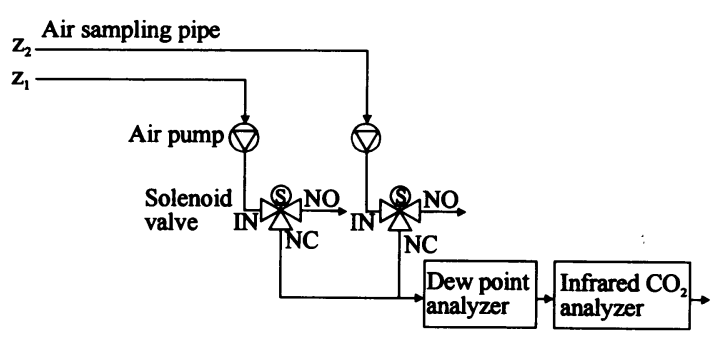

Fig. 2 Schematic diagram of the measuring system. 生物環境調節 (Environ. Control in Biol.) 
空気を鏡面式露点計および赤外線 $\mathrm{CO}_{2}$ 分析計に送り, 露点温度および $\mathrm{CO}_{2}$ 濃度を計測した. 気温は採取用パ イプの先端の位置で計測した. 露点温度と気温から絶 対湿度を求めた. 葉の裏面に熱電対(銅-コンスタンタ ン, 線径 $0.1 \mathrm{~mm}$ ) を密着させることによって葉温を計 測した. 各計測機器からの信号の処理および電磁弁の 通電・非通電状態の切換は汎用パーソナルコンピュー 夕 (PCX-300, ソニー (株) 製), 信号入出力装置 (Green kit 88,（株)イー・エス・ディ製）および自作の専用ソ フトウエアを用いて行った。

計測開始直前に 1 回目の灌水を苗個体群の底面から 行った.計測開始 16 時間後に 2 回目の灌水を培地表面 から行った。

\section{3. 純光合成速度, 蒸発散速度, 顕熱輸送速度および 潜熱輸送速度の算定方法}

苗個体群の純光合成速度, 蒸発散速度, 顕熱輸送速 度および潜熱輸送速度の算定方法には, 先に報告した 微気象学的方法と科量法を応用した計測方法 (Shibuya et al., 1997) を用いた。 その概要を以下に示 す.

苗個体群の蒸発散速度 $(E)$ は式 (1)のように表され, 苗個体群の重量の実測值から求めることができる。ま た, $E$ は拡散理論から式(2)のように表される.拡散係 数 $(K)$ は (1) 式によって求めた $E$ と苗個体群上の絶対 湿度勾配 $\left(q_{2}-q_{1}\right) /\left(z_{2}-z_{1}\right)$ の実測值を用いて求めるこ とができる. 苗個体群の純光合成速度 $(P)$ は拡散理論 から式(3)のように表され，(2)式で求めた $K$ と $\mathrm{CO}_{2}$ 濃度勾配 $\left(C_{2}-C_{1}\right) /\left(z_{2}-z_{1}\right)$ の実測值を用いて求める ことができる。顕熱輸送速度 $\left(H_{\mathrm{s}}\right)$ は拡散理論から式 (4)のように表され, (2) 式で求めた $K$, 気温勾配 $\left(T_{2}-\right.$ $\left.T_{1}\right) /\left(z_{2}-z_{1}\right)$ の実測値および空気の熱容量 $\left(\rho_{\mathrm{a}} \cdot c_{\mathrm{p}}\right)$ か ら求めることができる。潜熱輸送速度 $\left(H_{1}\right)$ は $E$ に水 の蒸発潜熱 $(\lambda)$ を乗じることによって求めることがで きる(式 $(5))$.

$$
E=\frac{W_{1}-W_{2}}{t_{2}-t_{1}} \cdot \frac{1}{A}
$$

$E$ : 苗個体群の蒸発散速度 $\left(\mathrm{gH}_{2} \mathrm{O} \mathrm{m} \mathrm{m}^{-2} \mathrm{~s}^{-1}\right)$

$W_{1}, W_{2}$ : 時間 $t_{1}, t_{2}\left(t_{1}<t_{2}\right)$ における苗個体群の重量 (g)

$A$ : 重量計測に用いた苗個体群の面積 $\left(\mathrm{m}^{2}\right)$

$$
E=-K \frac{q_{2}-q_{1}}{z_{2}-z_{1}}
$$

$K$ : 拡散係数 $\left(\mathrm{m}^{2} \mathrm{~s}^{-1}\right)$

$q_{1}, q_{2}$ : 高さ $z_{1}, z_{2}\left(z_{1}<z_{2}\right)$ における絶対湿度

Vol. 35, No. 3 (1997)

$$
P=K \frac{C_{2}-C_{1}}{z_{2}-z_{1}}
$$

$P$ : 純光合成速度 $\left(\mathrm{gCO}_{2} \mathrm{~m}^{-2} \mathrm{~s}^{-1}\right)$

$C_{1}, C_{2}$ : 高さ $z_{1}, z_{2}\left(z_{1}<z_{2}\right)$ における $\mathrm{CO}_{2}$ 濃度

$$
\left(\mathrm{gCO}_{2} \mathrm{~m}^{-3}\right)
$$

$$
H_{\mathrm{s}}=-K \frac{\rho_{\mathrm{a}} \cdot c_{\mathrm{p}}\left(T_{2}-T_{1}\right)}{z_{2}-z_{1}}
$$

$H_{\mathrm{s}}$ : 顕熱輸送速度 $\left(\mathrm{W} \mathrm{m}^{-2}\right)$

$\rho_{\mathrm{a}}$ : 空気密度 $\left(\mathrm{g} \mathrm{m}^{-3}\right)$

$c_{\mathrm{p}}$ : 定圧比熱 $\left(\mathrm{J} \mathrm{g} \mathrm{g}^{-1}{ }^{\circ} \mathrm{C}^{-1}\right)$

$T_{1}, T_{2}$ : 高さ $z_{1}, z_{2} \quad\left(z_{1}<z_{2}\right)$ における気温 $\left({ }^{\circ} \mathrm{C}\right)$

$$
H_{1}=\lambda \cdot E
$$

$H_{1}$ : 潜熱輸送速度 $\left(\mathrm{W} \mathrm{m}^{-2}\right)$

$\lambda:$ 蒸発潜熱 $\left(\mathrm{J} \mathrm{gH}_{2} \mathrm{O}^{-1}\right)$

\section{4. 水利用効率の算定方法}

水利用効率 $(W U E)$ は一般に, 単位量の乾物を生産 する間に蒸発散によって消費された水量と定義される (Kramer, 1983)。植物は $\mathrm{CO}_{2}$ （分子量：44）を吸収し て $\mathrm{CH}_{2} \mathrm{O}$ (分子量：30）を乾物として生産することか ら,Pの 30/44 倍を植物の乾物生産速度と仮定すると, $W U E$ は式(2)と式(3) から式(6)のように表される.す なわち $W U E$ は $z_{1}, z_{2}$ 間の絶対湿度差 $\left(q_{2}-q_{1}\right)$ と $\mathrm{CO}_{2}$ 濃度差 $\left(C_{2}-C_{1}\right)$ の実測值を用いて求めることができ る.

$$
W U E=\frac{E}{h \cdot P}=-\frac{1}{h} \cdot \frac{q_{2}-q_{1}}{C_{2}-C_{1}}
$$

$W U E:$ 水利用効率

$h$ : 純光合成速度を乾物生産速度に変換する係数（= 30/44)

\section{5. ボーエン比の算定方法}

苗個体群のボーエン比 $(\beta)$ は式(2), 式(4)および式 (5)より, 式(7)のように表される.すなわち, $\beta$ は気温 差 $\left(T_{2}-T_{1}\right)$ および絶対湿度差 $\left(q_{2}-q_{1}\right)$ の実測値, 空 気の熱容量 $\left(\rho_{\mathrm{a}} \cdot c_{\mathrm{p}}\right)$, 水の蒸発潜熱 $(\lambda)$ を用いて求め ることができる。

$$
\beta=\frac{H_{\mathrm{s}}}{H_{1}}=\frac{\rho_{\mathrm{a}} \cdot c_{\mathrm{p}}\left(T_{2}-T_{1}\right)}{\lambda\left(q_{2}-q_{1}\right)}
$$

$\beta:$ ボーエン比

\section{6. 水蒸気拡散抵抗の算定方法}

ある 2 点間における拡散抵抗は, その 2 点間におけ る濃度差を濃度差によって生じたフラックスで除する ことによって求めることができる (Oke, 1987). 本研 究では苗個体群をマスとしてとらえ, その仮想表面と 
大気との水蒸気交換を律則する抵抗（気孔抵抗，葉面 境界層抵抗など）の合成抵抗を苗個体群の水蒸気拡散 抵抗と定義し, フラックスを蒸発散速度, 濃度差を葉 温における飽和絶対湿度と高さ $z_{1}$ における絶対湿度 との差として, 苗個体群と高さ $z_{1}$ との間の水蒸気拡散 抵抗を算定した（(8)式，Oke, 1987 を一部改定).

$$
R=\frac{q_{\mathrm{L}}-q_{2}}{E}
$$

$R:$ 水蒸気拡散抵抗 $\left(\mathrm{s} \mathrm{m}^{-1}\right)$

$q_{\mathrm{L}}$ : 葉温における飽和絶対湿度 $\left(\mathrm{gH}_{2} \mathrm{O} \mathrm{m}^{-3}\right)$

\section{7. 培地の体積含水率の算定方法}

培地の体積含水率は, 苗個体群の重量, 苗個体群の 乾燥重量, 培地の容積および苗の含水量から式(9)を用 いて近似的に求めることができる.ただし, 苗の根部 の容積は培地の容積に対して無視できるほど小さいと 仮定する.

$$
l=\frac{a\left(W-W_{\mathrm{d}}-W_{\mathrm{p}}\right)}{V} \times 100
$$

$l:$ 培地の体積含水率 (\%)

$W:$ 苗個体群の重量 $(\mathrm{g})$

$W_{\mathrm{d}}:$ 苗個体群の乾燥重量 $(\mathrm{g})$

$W_{\mathrm{p}}$ : 苗個体群あたりの苗の含水量 $(\mathrm{g})$, 本実験では

$$
W_{\mathrm{p}}=80 \mathrm{~g} \text { とした。 }
$$

$V:$ 苗個体群あたりの培地の体積 $\left(\mathrm{m}^{3}\right)$

$a:$ 水の重量を体積に変換する係数 $\left(\fallingdotseq 10^{-6}, \mathrm{~m}^{3} \mathrm{~g}^{-1}\right)$

\section{結果}

\section{1. 苗個体群の面䅡含水量}

苗個体群の面積あたりの含水量（苗個体群の重量か ら苗個体群の乾燥重量を引いた值を苗個体群のトレイ 面積で除した值, 以下, 面積含水量) の経時変化を Fig. 3 に示す．計測開始時の苗個体群の面積含水量は 8.8 $\mathrm{kg} \mathrm{m}^{-2}$ であった。このときの培地の体積含水率は $70 \%$ であった(培地の最小容水量に相当). 苗個体群からの 蒸発散によって面積含水量は経時的に隇少した。計測

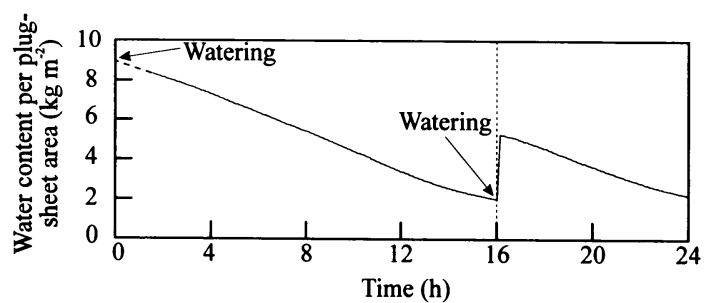

Fig. 3 Time course of water content per plug-sheet area.
開始 16 時間後に行った 2 回目の灌水によって面積含 水量は $2.0 \mathrm{~kg} \mathrm{~m}^{-2}$ から $5.2 \mathrm{~kg} \mathrm{~m}^{-2}$ へと増加した。

\section{2. 純光合成速度}

純光合成速度の経時変化を Fig. 4(a) に示す. 計測 開始 15 時間後から 17 時間後の間は, 苗が萎れ, 苗個 体群のキャノピーの高さが低下したことによって，拡 散係数の算定を正確に行うことができなかったために 欠測とした。純光合成速度は計測開始から 13 時間はほ ほ一定值であったが, 計測開始 13 時間後（面積含水 量: $\left.2.9 \mathrm{~kg} \mathrm{~m}^{-2}\right)$ に減少し始めた. 計測開始 16 時間後に 行った 2 回目の灌水によって, 純光合成速度は計測開 始から 18 時間後に計測開始時と同じレベルに戻った。 計測開始 20 時間後 (面積含水量 : $3.6 \mathrm{~kg} \mathrm{~m}^{-2}$ ) に純光合 成速度は再び減少し始めた. 計測開始 13 時間後および 20 時間後における培地の体積含水率はそれぞれ，12\% および $19 \%$ であった. 面積含水量と純光合成速度の関 係を Fig. 5 に示す. 1 回目の灌水後（計測開始 0 時間 後から 15 時間後) では, 面積含水量が $2.9 \mathrm{~kg} \mathrm{~m}^{-2}$ を下 回ると, 2 回目の灌水後(計測開始 17 時間後から 24 時 間後)では, 面積含水量が $3.6 \mathrm{~kg} \mathrm{~m}^{-2}$ を下回ると, 純光 合成速度は面積含水量の減少に伴って一次関数的に減 少した．面積含水量の減少に対する純光合成速度の減
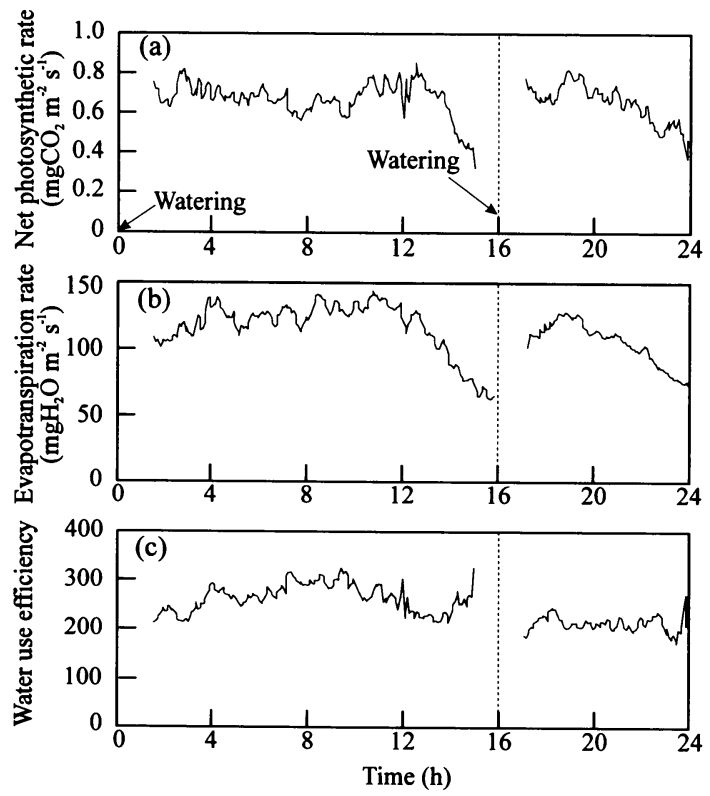

Fig. 4 Time courses of (a) net photosynthetic rate, (b) evapotranspiration rate and (c) water use efficiency of the plug sheet.

Data are shown as running average for 16 minutes.

生物環境調節 (Environ. Control in Biol.) 


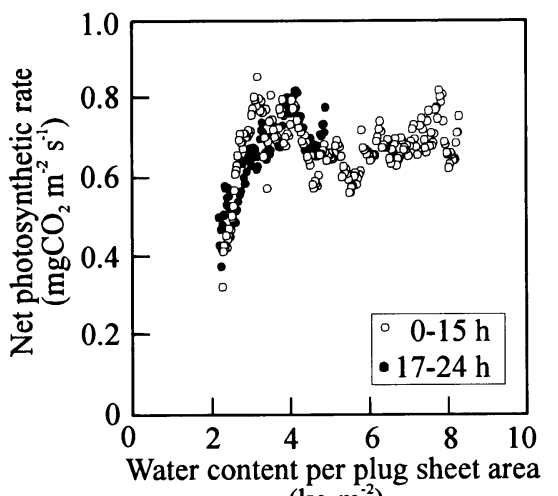

$\left(\mathrm{kg} \mathrm{m}^{-2}\right)$

Fig. 5 Relationship between water content per plugsheet area and net photosynthetic rate of the plug sheet after the first watering $(0 \mathrm{~h})$ and the second watering $(16 \mathrm{~h})$.

Open and solid circles denote the data for 0-15 $\mathrm{h}$ and $17-24 \mathrm{~h}$ after the start of experiments, respectively.

少の割合は, 2 回目の灌水後では 1 回目の灌水後より も小である傾向が見られた。

\section{3. 蒸発散速度}

蒸発散速度の経時変化を Fig. 4(b) に示す. 計測開 始 16 時間後から 17 時間後の間は, 2 回目の灌水によ る外乱のために欠測とした。蒸発散速度は計測開始 11 時間はほほ一定值であったが，計測開始 11 時間後(面 積含水量: $3.9 \mathrm{~kg} \mathrm{~m}^{-2}$ ) に減少し始めた。計測開始 16 時 間後に行った 2 回目の灌水によって, 蒸発散速度は計 測開始 19 時間後に計測開始時と同じレベルに戻った。 計測開始 19 時間後 (面積含水量 : $4.1 \mathrm{~kg} \mathrm{~m}^{-2}$ ) に蒸発散 速度は再び減少し始めた。計測開始 11 時間後および 19 時間後における培地の体積含水率はそれぞれ， $21 \%$ および $23 \%$ であった. 面積含水量と蒸発散速度の関係 を Fig. 6 に示す. 1 回目の灌水後（計測開始 0 時間後 から 16 時間後)では, 面積含水量が $3.9 \mathrm{~kg} \mathrm{~m}^{-2}$ を下回 ると, 2 回目の灌水後(計測開始 17 時間後から 24 時間 後)では, 面積含水量が $4.1 \mathrm{~kg} \mathrm{~m}^{-2}$ を下回ると, 蒸発散 速度は面積含水量の減少に伴って一次関数的に減少し た．面積含水量の減少に対する蒸発散速度の減少の割 合は, 2 回目の灌水後では 1 回目の灌水後よりも小で ある傾向が見られた。

\section{4. 水利用効率}

水利用効率の経時変化を Fig. 4(c) に示す. 水利用効 率は 215 から 330 であった. 水利用効率は計測開始 10 時間後に減少し始め, 計測開始 14 時間後に増加し始め

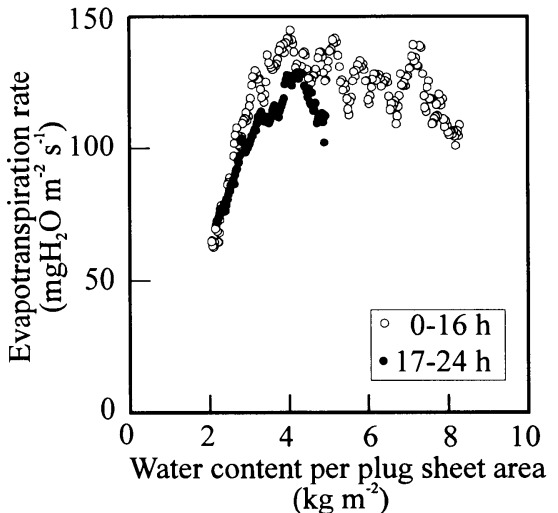

Fig. 6 Relationship between water content per plugsheet area and evapotranspiration rate of the plug sheet after the first watering $(0 \mathrm{~h})$ and the second watering $(16 \mathrm{~h})$.

Open and solid circles denote the data for 0-16 $\mathrm{h}$ and $17-24 \mathrm{~h}$ after the start of experiments, respectively.
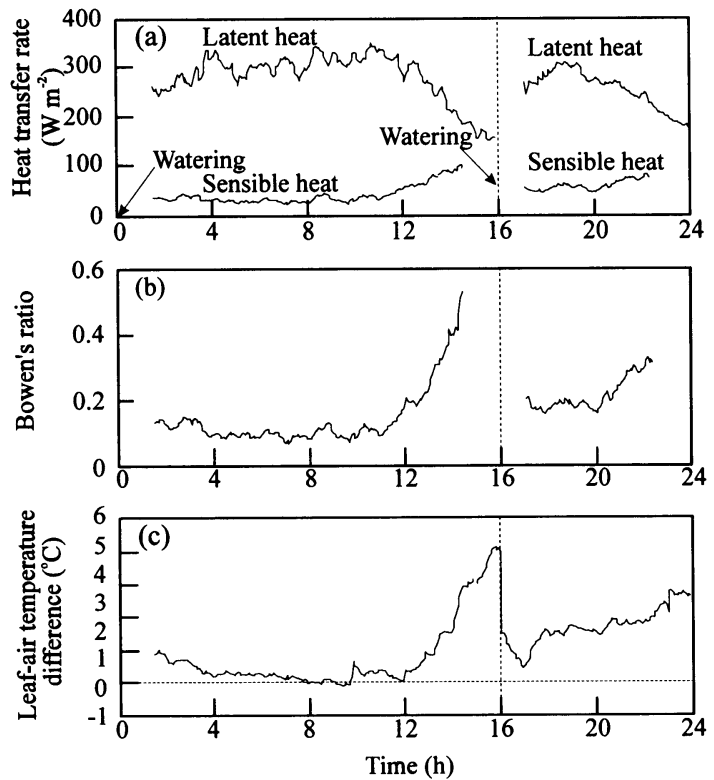

Fig. 7 Time courses of (a) sensible and latent heat transfer rates, (b) Bowen's ratio and (c) leaf-air temperature difference of the plug sheet.

Data are shown as running average for 16 minutes.

\section{る傾向が見られた。}

\section{5. 顕熱および潜熱輸送速度}

顕熱および潜熱輸送速度の経時変化を Fig. 7(a) に 
示す. 計測開始 15 時間後から 17 時間後の間は, 苗が 萎れ, 苗個体群のキャノピーの高さが低下したことに よって, 拡散係数の算定を正確に行うことができな かったために顕熱輸送速度は欠測とした。計測開始 16 時間後から 17 時間後の間は, 2 回目の灌水による外乱 のために潜熱輸送速度は欠測とした。顕熱輸送速度は 計測開始から 11 時間はほほ一定值であったが計測開 始 11 時間後 (面積含水量 : $3.9 \mathrm{~kg} \mathrm{~m}^{-2}$ ) に増加し始め た。潜熱輸送速度は計測開始から 11 時間はほほ一定值 であったが, 計測開始 11 時間後に減少し始めた. 計測 開始 11 時間後における培地の体積含水率は $21 \%$ で あった。

\section{6. ボーエン比}

ボーエン比の経時変化を Fig. 7(b) に示す.ボーエ ン比は計測開始から 11 時間はほほ一定值であったが, 計測開始 11 時間後(面積含水量 : $3.9 \mathrm{~kg} \mathrm{~m}^{-2}$, 培地の体 積含水率：21\%）に増加し始めた。

\section{7. 葉気温差}

葉気温差（葉温から気温を引いた値）の経時変化を Fig. 7(c) に示す. 葉気温差は計測開始から 12 時間は ほほ一定值であったが, 計測開始 12 時間後 (面積含水 量 : $3.4 \mathrm{~kg} \mathrm{~m}^{-2}$ ) に増加し始めた. 計測開始 16 時間後に 行った 2 回目の灌水によって葉気温差は計測開始 17 時間後に計測開始時と同じレベルに戻った．計測開始 12 時間後および 17 時間後における培地の体積含水率

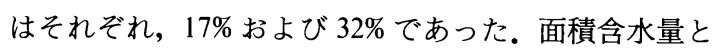

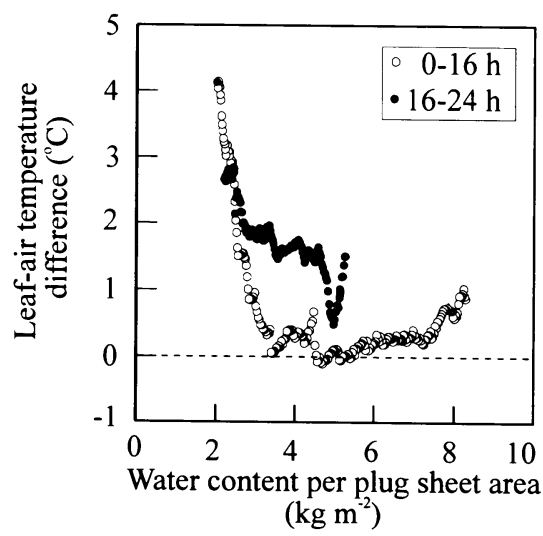

Fig. 8 Relationship between water content per plugsheet area and leaf-air temperature difference of the plug sheet after the first watering $(0 \mathrm{~h})$ and the second watering $(16 \mathrm{~h})$.

Open and solid circles denote the data for 0-16 $h$ and $16-24 h$ after the start of experiments, respectively.
葉気温差の関係を Fig. 8 に示す. 1 回目の灌水後（計 測開始 0 時間後から 16 時間後) では, 面積含水量が 3.4 $\mathrm{kg} \mathrm{m}^{-2}$ を下回ると, 2 回目の灌水後 (計測開始 16 時間 後から 24 時間後) では, 面積含水率が $4.9 \mathrm{~kg} \mathrm{~m}^{-2}$ を下 回ると, 葉気温差は面積含水量の減少に伴って一次関 数的に増加した. 面積含水量の減少に対する葉気温差 の増加の割合は, 2 回目の灌水後では 1 回目の灌水後 よりも小である傾向が見られた。

\section{8. 水蒸気拡散抵抗}

水蒸気拡散抵抗の経時変化を Fig. 9 に示す。計測開 始 15 時間後から 17 時間後の間は, 苗が萎れ, 苗個体 群の高さが低下したことによって, 葉温の計測位置と 絶対湿度の計測位置 $z_{1}$ との距離が増大したために欠 測とした。水蒸気拡散抵抗は計測開始から 13 時間後は ほほ一定值であったが, 計測開始 13 時間後に増加し始 めた.計測開始 16 時間後に行った 2 回目の灌水によっ て水蒸気拡散抵抗は計測開始 17 時間後に計測開始時 のレベルに戻った.

\section{9. 拡散 係 数}

拡散係数の経時変化を Fig. 10 に示す．計測開始 15 時間後から 17 時間後の間は, 苗が萎れ, 苗個体群の高 さが低下したことによって, 絶対湿度の計測位置 $z_{2}$ が 境界層外となり，拡散係数の算定を正確に行うことが

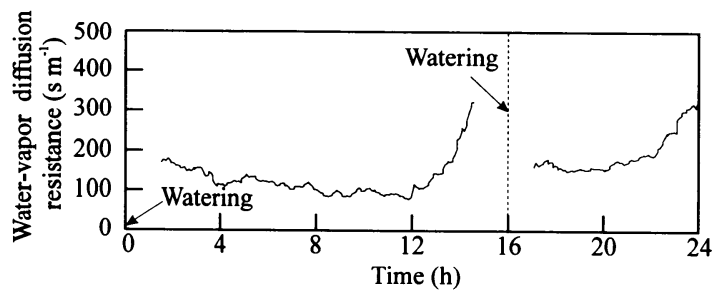

Fig. 9 Time course of water-vapor diffusion resistance of the plug sheet.

Data are shown as running average for 16 minutes.

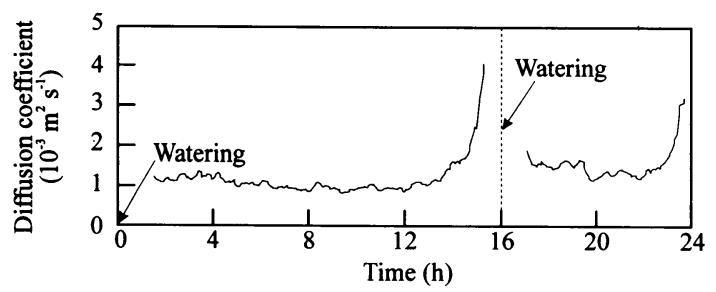

Fig. 10 Time course of diffusion coefficient above the plug sheet.

Data are shown as running average for 16 minutes.

生物環境調節 (Environ. Control in Biol.) 
できなかったために欠測とした．拡散係数は計測開始 から 14 時間はほぼ一定値であったが, 計測開始 14 時 間後に増大し始めた。計測開始 16 時間後に行った 2 回 目の灌水によって拡散係数は計測開始 17 時間後に計 測開始時のレベルに戻った.

\section{考察}

目視によるしおれの初期兆候は計測開始約 12 時間 後に観察され, 14 時間後には明らかなしおれが観察さ れた。計測開始 11 時間から 13 時間後（面積含水量： $3.9 \mathrm{~kg} \mathrm{~m}^{-2}$ から $2.9 \mathrm{~kg} \mathrm{~m}^{-2}$; 培地の体積含水率: $21 \%$ から 12\%)に打ける純光合成速度, 蒸発散速度, 顕熱輸 送速度, 潜熱輸送速度, ボーエン比, 水蒸気拡散抵抗 および葉気温差の変動は, 培地の水ポテンシャルが減 少したことによって苗が水ストレスを受けたことに起 因すると考えられる.葉気温差が計測開始 12 時間後に 増大したのは, 苗の蒸散速度が減少したことを示唆す る.純光合成速度は計測開始 15 時間後に計測開始時に おける值のほほ 50\% となった。 Brix（1962）がトマト のポット苗 (ポットの径：約 $18 \mathrm{~cm}$ )を用いて行った研 究では, 光合成速度は灌水終了約 170 時間後に灌水直 後の值のほほ $50 \%$ となった。本研究において, 灌水後, 純光合成速度が灌水直後の值の $50 \%$ に減少するまで の時間が Brix (1962) の研究に比べて短かったことは, 主に培地量が Brix（1962）の実験に比べて少なかった ためと考えられる.

1 回目の灌水後は, 蒸発散速度, 葉気温差, 純光合成 速度の順に, 2 回目の灌水後は葉気温差, 蒸発散速度, 純光合成速度の順にそれぞれの值が変動し始める傾向 が見られた. Brix (1962) は水ストレスの増加に伴う光 合成速度の低下と蒸散速度の低下との間には高い相関 が見られることを指摘している.しかし本研究の結果 では, 蒸散速度は純光合成速度よりも早く水ストレス による低下を始めたと考えられる。水利用効率は計測 開始 10 時間後に減少し始める傾向が見られた。これは 蒸発散速度の低下が純光合成速度の低下よりも早く始 まったことを示唆している. 2 回目の灌水後では 1 回 目の灌水後よりも高い体積含水率で蒸発散速度, 純光 合成速度および葉気温差が変動し, また, 面積含水量 の減少に対する各值の変動の割合は, 2 回目の灌水後 では 1 回目の灌水後よりも小である傾向が見られた。

これは 2 回目の灌水前に苗が水ストレスを受けたこ と, および 1 回目と 2 回目の灌水方法および灌水量が 異なることに起因すると考えられる.
顕熱輸送速度および潜熱輸送速度が計測開始 11 時 間後にそれぞれ増加および減少し始め, ボーエン比が 計測開始 11 時間後に増加し始めたのは, 計測開始 11 時間後に, 苗個体群の蒸発散速度の低下によって, 苗 個体群上面への純放射に対する潜熱輸送速度の割合が 減少し, 顕熱輸送速度の割合が増加したことを示す. 顕熱輸送速度に潜熱輸送速度を加えた值が苗個体群上 における短波放射束密度より大であったのは, グロー スチャンバの光源からの長波放射の影響が比較的大き く, 苗個体群上の長波放射収支が鉛直下向きに正で あったためと考えられる。また, 顕熱輸送速度に潜熱 輸送速度を加えた值は一定值ではなかった。これは, 苗個体群下面など, 苗個体群上, 鉛直上向き方向以外 にも顕熱が輸送されたためであると考えられる。ボー エン比は(7)式によって比較的簡易に求めることがで き, また, 計測誤差も比較的小さいと考えられるので, 苗の水ストレス状態の指標として有効であると考えら れる。

純光合成速度, 蒸発散速度, 顕熱輸送速度, 潜熱輸 送速度, ボーエン比, 水蒸気拡散抵抗および葉気温差 の経時変化から, 本研究において, 計測開始 11 から 13 時間後 (面積含水量: $3.9 \mathrm{~kg} \mathrm{~m}^{-2}$ から $2.9 \mathrm{~kg} \mathrm{~m}^{-2}$; 培地 の体積含水率： $21 \%$ から $12 \%$ ）における培地の水ポテ ンシャルは永久しおれ点であると推測される．永久し おれ点付近では, わずかな含水量の変化で大きな水ポ テンシャルの変化が起こる（例えば, Kramer, 1983) ために, 計測開始 11 から 13 時間後以降では, 比較的 小さな含水量の変化に対して純光合成速度, 蒸発散速 度, 顕熱輸送速度, 潜熱輸送速度, ボーエン比, 水蒸 気拡散抵抗および葉気温差が大きく変動したものと考 えられる.このことは培地量が極端に少なく, 培地の 水分状態が蒸発散や灌水によって変化しやすいセル成 型苗において特に留意すべき問題である. 本研究にお いて推定した培地の体積含水率の值は, 苗の含水量の 計測を十分に行わなかったために，正確な值とはいえ ない. 今後, 培地の体積含水率を正確に推定すること によって, 培地の水分状態と苗の生育状態との関係を 定量的に明らかにする必要がある.

水蒸気拡散抵抗が計測開始 13 時間後に増大し始め たのは, 主に気孔抵抗の増大に起因すると考えられる. 本研究では, 葉温における飽和絶対湿度を苗個体群全 体の絶対湿度の指標として用いたが, 実際は, 苗の葉 の絶対湿度の指標と苗および培地を含めた絶対湿度の 指標は異なり, また, 苗個体群全体の絶対湿度の指標 
は苗および培地の水ポテンシャルによって異なると考 えられる. 従って, 本計測方法によって水蒸気拡散抵 抗を正確に求めるためには, 苗および培地を含めた苗 個体群を代表した絶対湿度の指標を連続的に算定する 必要があると考えられる。

拡散係数が計測開始 14 時間後に増大し始めたのは, 苗個体群と苗個体群上の空気との温度差が増大し, 苗 個体群上の空気の浮力が増加したことに起因すると考 えられる.拡散係数は分子拡散係数（オーダー：10 $\left.\mathrm{m}^{2} \mathrm{~s}^{-1}\right)$ の $10^{2}$ 倍以上の大きさであったことから, 分子 量の違いによる分子拡散係数の違いは無視でき，ここ で得られた拡散係数は水蒸気以外の物質および熱に対 する拡散係数としても用いることができることが確認 できた。

\section{結論}

本研究で示した計測方法により, 比較的少ない計測 要素から苗個体群の物質および熱収支特性が多面的に 解析された. 苗個体群における純光合成速度, 蒸発散 速度, 顕熱輸送速度および潜熱輸送速度は, 永久しお れ点以下の培地の水ポテンシャルにおいて, 比較的小 さな含水量の変化で大きく変動することが示唆され た.これらの変動は苗の水ストレス状態の変動に対応 したことから, 本研究で用いた計測方法によって, 非 接触で動的に個体群単位での苗の水ストレス状態を推
定できると考えられる.

実験材料のセル成型苗を提供して下さったダイヤト ピー農芸(株)の根本 修氏に謹んで感謝の意を表す。

\section{文献}

Brix, H. 1962. The effect of water stress on the rates of photosynthesis and respiration in tomato plants and loblolly pine seedlings. Physiol. Plant. 15 : 10-20.

Kim, Y. H., Kozai, T., Kubota, C., Kitaya, Y. 1996a. Design of a wind tunnel for plug seedlings production under artificial lighting. Acta Hortic. 440 : 153-158.

Kim, Y. H., Kozai, T., Kubota, C., Kitaya, Y. 1996b. Effects of air current speeds on the microclimate of plug stand under artificial lighting. Acta Hortic. $440: 354-359$.

Kramer, P. J. 1983. Water Relations of Plants. Academic Press, Orlando, pp 489.

Lemon, G. 1963. Energy and water balance of plant communities. In "Environmental control of plant growth," (ed. by Evans, L. T.), Academic Press, New York, p 55-76.

Milks, R. R., Fonteno, W. C., Larson, R. A. 1989. Hydrology of horticultural substrates : III. Predicting air and water content of limited-volume plug cells. J. Am. Soc. Hortic. Sci. 114(1) : 57-61.

Oke, T. R. 1987. Boundary Layer Climates. Ed. 2. Methuen, New York, pp 435.

Shibuya, T., Kitaya, Y., Kozai, T. 1997. Dynamic measurements of net photosynthetic and evapotranspiration rates, and sensible and latent heat transfer rates of plug sheets based on micrometeorological and weighing methods. (Japanese text with English abstract) Environ. Control in Biol. 35 : 71-76. 